\title{
Evaluation of the frequency of childhood hospitalization due to thermal injuries in the Provincial Polyclinical Hospital in Toruń, Poland, 2007-2011
}

\author{
Ewa Barczykowska', Małgorzata Cyran², Aneta Zreda-Pikies' ${ }^{1}$, Małgorzata Kowalczyk ${ }^{3}$, \\ Robert Ślusarz ${ }^{4}$, Andrzej Kurylak ${ }^{1}$ \\ ${ }^{1}$ Department of Paediatric Nursing, Collegium Medicum, Nicolaus Copernicus University, Toruń, Poland \\ ${ }^{2}$ Department of Anesthesiology and Intensive Therapy, Collegium Medicum, Nicolaus Copernicus University, Toruń, Poland \\ 3 Paediatrics, Urology and Paediatric Surgery Department, Children's Hospital, L. Rydygier Provincial Hospital, Toruń, Poland \\ ${ }^{4}$ Neurological and Neurosurgical Nursing Department, Collegium Medicum, Nicolaus Copernicus University, Toruń, Poland
}

Barczykowska E, Cyran M, Zreda-Pikies A, Kowalczyk M, Ślusarz R, Kurylak A. Evaluation of the frequency of childhood hospitalization due to thermal injuries in the Provincial Polyclinical Hospital in Toruń, Poland, 2007-2011. Ann Agric Environ Med. $2018 ;$ 25(1): 26-30. doi: $10.5604 / 12321966.1233563$

\begin{abstract}
Introduction. Burns constitute the most common and severe injuries suffered in childhood.

Objective. The study was aimed at providing a retrospective analysis of the etiology, location, extent and depth of burns, as well as treatment methods and length of hospital stay.

Materials and method. A retrospective analysis of 508 cases of children treated due to a thermal injury between 1 January 200731 December 2011 was conducted at the Department of Paediatrics, Urology and Paediatric Surgery, Children's Hospital, L. Rydygier Provincial Hospital in Toruń, Poland.

Results. The sample group included more boys (58.9\%) than girls (41.1\%). The most numerous group comprised children aged 1-2 years (44.5\%). Burns were largely suffered at home (91.9\%). Injuries were largely caused by thermal burns (99.2\%). Half of the children sustained injury to one body area (51.4\%), while every third sufferer (37.9\%) was affected by burns to body parts prone to trigger shock. Burns up to $5 \%$ of the Total Body Surface Area (TBSA) were suffered by half (51.2\%) of the children. Most of the patients underwent conservative treatment (89.4\%).

Conclusions. Burns were mostly suffered by children at 1-2 years of age, with boys prevailing over girls. Injuries were largely suffered at the child's family home, in the afternoon or evening, while the child was in the care of the parents. Scalds, caused by hot liquid, constituted the most frequent type of injury. The most numerous group of affected children comprised burns to $\operatorname{limb}$ areas, and thorax with limbs, with the TBSA of up to $5 \%$. The great majority of the patients underwent conservative treatment, with a hospitalization period of up to 3 days.
\end{abstract}

\section{Key words}

burns, children, hospitalization

\section{INTRODUCTION}

Burns and scalds rank as one of the most common and severe childhood injuries $[1,2,3]$, second only to transportation injuries in terms of need for hospitalization [4]. Overall, $1 \%$ of our population suffer from diverse burns each year. In Poland, the number reaches approximately 300,000-400,000 people, with children constituting nearly $50-70 \%$, where $3 / 4$ of the cases refer to children at up to 4 years of age $[2,3]$. Mortality among burnt children amounts to $0.3 \%-9.2 \%$ [3]. $3 \%-10 \%$ of burns in children are estimated as nonaccidental $[4,5,6]$.

Burns are defined as inflammatory or/and necrotic lesions to integuments and tissues induced by miscellaneous types of thermal energy over the protective abilities of the human body' [7]. Even small portions of causative factors prove

Address for correspondence: Ewa Barczykowska, Collegium Medicum im. L. Rydygiera, ul. Łukasiewicza 1, UMK Torun, 85-821, Poland Tel.: 525855822

E-mail: ebarczykowska@interia.pl

Received: 11 March 2014; accepted: 11 December 2015; first published on February 2017 injurious, leaving lasting negative effects on the children's appearance and psychology [8]. Burn is a type of injury which entails long-term physical, psychological and economic consequences [9].

The family home is the most frequent scene of burns. The principal cause of burns in children is contact with hot liquids $[1,2,9-12]$, less frequently with flame [10] or with a hot object [2]. It may be assumed, that in developed countries, this problem is the effect of inadequate supervision over children [10]. Children suffer consequences of their natural need of acquiring new skills, of their inexperience, their unawareness of dangers, and of their parents' carelessness.

The study was conducted to determine the scope and the conditions of burns among children. Important epidemiological factors were analyzed: child's age, site and burn cause. The presence parents or other carers at the time of the event was also taken into consideration. Among others, the main parameters illustrating the burn wound were its location and size. Understanding burn causes and their tragic consequences may help to break the stereotype that burns among children are random events which cannot be prevented. 


\section{OBJECTIVE}

The research was aimed at providing a retrospective analysis of the etiology, location, extent and depth of burns, as well as treatment methods and length of hospital stay.

\section{MATERIALS AND METHOD}

A retrospective analysis of 508 cases of children treated with respect to a thermal burn from 1 January 2007-31 December 2011 was performed at the Department of Paediatrics, Urology and Paediatric Surgery, Children's Hospital, L. Rydygier Provincial Hospital in Torun, Poland.

The group comprised 299 boys (58.9\%) and 209 girls (41.1\%). Children aged 1-2 years constituted the majority - 226 individuals (44.5\%), followed by children at the age of up to 1 year - 118 persons (23.2\%), and individuals aged over 5 years - 100 sufferers (19.7\%). The least numerous age group involved children aged 3-5 years - persons (12.6\%).

Urban dwellers of cities with a population over 100,000 inhabitants accounted for half of the sample group -260 individuals (51.2\%), whereas rural dwellers constituted $38.2 \%$ of all the cases studied - 194 children. The least numerous group of 54 (10.6\%) sufferers represented urban dwellers of towns with a population below 100,000 inhabitants.

The retrospective study provided an analysis of the hospitalized children's medical records with respect to demographics (age, gender, and residence), circumstances (the scene of the injury, the person caring for the child, the causative factor, and the time of day the trauma took place), as well as the basic clinical data to describe the injury (location, burn surface area, treatment, and length of hospital stay). The study was conducted with the approval of the Nicolaus Copernicus University Bioethics Commission in Torun (KB 83/2013).

Statistical analysis was performed with the use of the standard functions of OpenOffice and Microsoft Excel 2010 spreadsheets, and the application of the Spearman's correlation coefficient (R), the non-parametric MannWhitney U, and the non-parametric Kruskal-Wallis one-way analysis of variance by ranks. The statistical significance (p) was assumed at $\mathrm{p} \leq 0.05$.

\section{RESULTS}

During 2007-2011, the Paediatrics, Urology and Paediatric Surgery Department - Children's Hospital - L. Rydygier Provincial Hospital in Toruń hospitalized 9,083 children overall, including 508 cases of burns. Patients treated for burns constituted an average of $5.59 \%$ of all the cases hospitalized in a year $(5.01 \%$ in $2007,5.99 \%$ in $2008,6.19 \%$ in $2009,5.64 \%$ in 2010 , and $5.20 \%$ in 2011 ).

The circumstances of the injury: child's age, scene, person caring for the child at the time of the injury, and the causative factor, were taken into account.

The great majority of the burns took place at home, the average age of the sufferers being 3 years and a month. However, burns suffered in the backyard involved older children, i.e. aged 9 years and 8 months. A low, statistically significant correlation was reported between age and the scene of injury $(\mathrm{p}<0.05)$ (Tab. 1).
Table 1. Injury scene and average age of affected children

\begin{tabular}{lccc}
\hline Scene & $\mathrm{N}$ & Average & SD \\
\hline family house & 467 & 3.1 & 3.652 \\
\hline Play ground & 23 & 9.8 & 5.228 \\
\hline hospital & $\mathbf{1}$ & $\mathbf{1 . 5}$ & $\mathbf{0 . 0 0 0}$ \\
\hline State Children's Home & 1 & 1.4 & 0.000 \\
\hline no data & 16 & - & - \\
\hline $\mathrm{R}=0.262 ; \mathrm{t}(\mathrm{N}-2)=6.018 ; \mathrm{p}=0.000$ & & &
\end{tabular}

In terms of adults caring for the child at the time of injury, most burns were suffered while both parents were attending to the child (66.7\%), and every fifth case took place when only the mother was present (Tab. 2).

Table 2. Child's carer at time of injury

\begin{tabular}{lcc}
\hline Child's carer & Number $(\mathrm{N})$ & Percentage (\%) \\
\hline parents & 339 & 66.7 \\
\hline father & 17 & 3.3 \\
\hline mother & 107 & 21.1 \\
\hline grandmother & 9 & 1.8 \\
\hline baby-sitter & 4 & 0.8 \\
\hline sister & 3 & 0.6 \\
\hline no data & 29 & 5.7 \\
\hline Total & 508 & 100.0 \\
\hline
\end{tabular}

Thermal burns were reported to be the most common cause of hospitalization - in 492 children (99.2\%), including 430 cases $(86.7 \%)$ of accidents with hot liquids and 62 patients (12.5\%) who sustained contact burns. Sunburns affected 2 children $(0.4 \%)$. Moreover, single cases of burns were caused by pepper spray (0.2\%) and electrical shock (0.2\%) (Tab. 3 ).

With regard to the time of day when burns were suffered, the accidents largely occurred in the afternoon (30.3\%) and evening (40.9\%) (Tab. 4).

Considering the parameters of burn injuries, the study focused on the location, extent and depth of the wound.

According to the medical records, wound evaluation in children included the following body areas: head, neck, thorax, limbs, hands, feet, and perineum. Among the hospitalized children, 261 (51.4\%) cases referred to burns of one body region, whereas 247 patients (48.6\%) suffered injuries to multiple body regions, with 2 regions affected in 149 cases (29.35\%), 3 body regions affected by burns in 69 children (13.6\%), and 4 body regions affected in 28 young sufferers (5.5\%). Most commonly, burns affected limbs - 136 cases (26.8\%), and limbs with thorax - in 94 children (18.5\%).

It should be noted that many burns affected particularly dangerous body areas, i.e. body parts prone to trigger shock (head, face, neck, feet, and perineum) - diagnosed in 193 children (37.9\%) (Tab. 5).

Following analysis of the extent of burns, it was reported that in half of the examined children - 260 individuals $(51.2 \%)$, the total body surface area (TBSA) was up to $5 \%$, every third child - 167 cases (32.9\%) suffered injuries of the TBSA at $6-10 \%$, and every tenth patient - 54 children (10.6\%) had $11-15 \%$ TBSA. In 2 children, the TBSA reached $21-25 \%$, and in one - over $25 \%$ (Tab. 6). 
Table 3. The number of hospitalized children by the causative factor and age group

\begin{tabular}{|c|c|c|c|c|c|c|c|c|}
\hline \multirow{2}{*}{$\begin{array}{l}\text { Child's age } \\
\text { Causes }\end{array}$} & \multicolumn{2}{|c|}{ up to 1 year } & \multicolumn{2}{|c|}{$1-2$ years } & \multicolumn{2}{|c|}{$3-5$ years } & \multicolumn{2}{|c|}{ over 5 years } \\
\hline & number & $\%$ & number & $\%$ & number & $\%$ & number & $\%$ \\
\hline tea & 38 & 32.2 & 88 & 39.5 & 25 & 39.7 & 21 & 21.2 \\
\hline coffee & 37 & 31.4 & 44 & 19.7 & 8 & 12.7 & 6 & 6.1 \\
\hline water & 25 & 21.2 & 53 & 23.8 & 16 & 25.4 & 22 & 22.2 \\
\hline soup & 3 & 2.5 & 10 & 4.5 & 4 & 6.3 & 6 & 6.1 \\
\hline fat & 1 & 0.8 & 7 & 3.1 & 2 & 3.2 & 5 & 5.1 \\
\hline milk & 1 & 0.8 & 4 & 1.8 & 1 & 1.6 & 2 & 2.0 \\
\hline tar & 0 & 0.0 & 0 & 0.0 & 0 & 0.0 & 1 & 1.0 \\
\hline fire ash & 0 & 0.0 & 3 & 1.3 & 0 & 0.0 & 0 & 0.0 \\
\hline $\begin{array}{l}\text { motorbike } \\
\text { exhaust } \\
\text { pipe }\end{array}$ & 0 & 0.0 & 0 & 0.0 & 0 & 0.0 & 5 & 5.1 \\
\hline flame & 0 & 0.0 & 4 & 1.8 & 2 & 3.2 & 17 & 17.2 \\
\hline fire & 4 & 3.4 & 2 & 0.9 & 0 & 0.0 & 1 & 1.0 \\
\hline iron & 2 & 1.7 & 4 & 1.8 & 1 & 1.6 & 0 & 0.0 \\
\hline oven & 7 & 5.9 & 3 & 1.3 & 0 & 0.0 & 2 & 2.0 \\
\hline $\begin{array}{l}\text { flammable } \\
\text { material } \\
\text { explosion }\end{array}$ & 0 & 0.0 & 0 & 0.0 & 0 & 0.0 & 3 & 3.0 \\
\hline grill & 0 & 0.0 & 1 & 0.4 & 1 & 1.6 & 0 & 0.0 \\
\hline $\begin{array}{l}\text { pepper } \\
\text { spray }\end{array}$ & 0 & 0.0 & 0 & 0.0 & 0 & 0.0 & 1 & 1.0 \\
\hline $\begin{array}{l}\text { electrical } \\
\text { shock }\end{array}$ & 0 & 0.0 & 0 & 0.0 & 0 & 0.0 & 1 & 1.0 \\
\hline sunburn & 0 & 0.0 & 0 & 0.0 & 1 & 1.6 & 1 & 1.0 \\
\hline Total & 118 & 100.0 & 223 & 100.0 & 61 & 100.0 & 94 & 100.0 \\
\hline
\end{tabular}

Table 4. Time of day when burns were sustained

\begin{tabular}{lcc}
\hline Time of day & No. of people (N) & Percentage (\%) \\
\hline morning (6-12) & 154 & 30.3 \\
\hline afternoon (12-17) & 208 & 40.9 \\
\hline evening (17-22) & 127 & 25.0 \\
\hline night (22-6) & 19 & 3.7 \\
\hline Total & $\mathbf{5 0 8}$ & $\mathbf{1 0 0 . 0}$ \\
\hline
\end{tabular}

Table 5. Number of hospitalized children by the location of burns

\begin{tabular}{lcc}
\hline Location of burns & No. people (N) & Percentage (\%) \\
\hline Limbs & 136 & 26.8 \\
\hline Thorax + limbs & 94 & 18.5 \\
\hline Hands & 45 & 8.9 \\
\hline Thorax & 40 & 7.9 \\
\hline Face + neck+ thorax + limbs & 28 & 5.5 \\
\hline Head + neck + thorax & 22 & 4.3 \\
\hline Head & 20 & 3.9 \\
\hline Face + thorax + limbs & 19 & 3.7 \\
\hline Face + thorax & 19 & 3.7 \\
\hline Feet & 19 & 3.7 \\
\hline Neck + thorax & 18 & 3.5 \\
\hline Neck + thorax + limbs & 15 & 3.0 \\
\hline Face + limbs & 11 & 2.2 \\
\hline Face + neck + limbs & 9 & 1.8 \\
\hline Head + neck & 5 & 1.0 \\
\hline Perineum + thorax + limbs & 4 & 0.8 \\
\hline Perineum + limbs & 4 & 0.8 \\
\hline Total & $\mathbf{5 0 8}$ & $\mathbf{1 0 0 . 0}$ \\
\hline
\end{tabular}

Table 6. Number of hospitalized children by the TBSA

\begin{tabular}{lcc}
\hline TBSA & No. of people (N) & Percentage(\%) \\
\hline up to 5\% & 260 & 51.2 \\
\hline $6-10 \%$ & 167 & 32.9 \\
\hline $11-15 \%$ & 54 & 10.6 \\
\hline $16-20 \%$ & 24 & 4.7 \\
\hline $21-25 \%$ & 2 & 0.4 \\
\hline over 25\% & 1 & 0.2 \\
\hline Total & $\mathbf{5 0 8}$ & $\mathbf{1 0 0 . 0}$ \\
\hline
\end{tabular}

Table 7. Treatment applied in years analysed

\begin{tabular}{|c|c|c|c|c|c|c|c|c|c|c|}
\hline \multirow{2}{*}{$\frac{\text { Year }}{\text { Treatment }}$} & \multicolumn{2}{|c|}{2007} & \multicolumn{2}{|c|}{2008} & \multicolumn{2}{|c|}{2009} & \multicolumn{2}{|c|}{2010} & \multicolumn{2}{|c|}{2011} \\
\hline & Number & $\%$ & Number & $\%$ & Number & $\%$ & Number & $\%$ & Number & $\%$ \\
\hline conservative & 98 & 98.0 & 103 & 96.3 & 93 & 85.3 & 84 & 82.4 & 76 & 84.4 \\
\hline surgical & 2 & 2.0 & 4 & 3.7 & 16 & 14.7 & 18 & 17.6 & 14 & 15.6 \\
\hline Total & 100 & 100.0 & 107 & 100.0 & 109 & 100.0 & 102 & 100.0 & 90 & 100.0 \\
\hline
\end{tabular}

In the period analysed, most patients were subject to conservative treatment - 454 children (89.4\%); nevertheless, surgical treatment generally tended to prevail (Tab. 7).

\section{DISCUSSION}

The presented work provides a retrospective evaluation of epidemiological trends of burns in children requiring hospitalization. Children hospitalized due to burns constituted an average of 5.59\% of all children hospitalized yearly. Similarly, Gontko et al. reported in their study that burnt children comprised $4.39 \%$ [10]. The proportion of hospitalization provided to children suffering from burns results, inter alia, from stringent recommendations for definite and immediate hospitalization of children in the following cases: major or moderate burns; minor but circumferential burns of limbs; burns to body parts prone to trigger shock; suspicion of deliberate action causing burns in children or that care provided to an affected child, will 
be insufficient, and particular types of burns (electrical, chemical, and inhalation burns) [9].

Next to the extent of burns, wound depth, medical history, affected body parts, and additional concomitant injuries, age is a significant factor affecting the severity and course of injury, as well as the risk of complications and the child's survival. Burnt children younger than 5 years and adults aged over 60 are especially susceptible to death, as opposed to other age groups sustaining similar or identical injuries [8].

The sample group of children hospitalized due to burns consisted largely of 1-2-year-olds (44.5\%). Analogical results were reported by Matuszczak et al. [1], Gontko et al. [10], Brodzińska [13], Grabowska et al.[14], and Rawlins [15]. A study conducted by Čelko showed that approximately 31\% of all hospitalizations due to burns referred to infants [11]. Drago et al. indicated children aged 0-2 years as typically prone to thermal burns due to their inherent curiosity, ways of reacting, and inexperience in terms of risk assessment [9]. Older age groups are characterized by a decreased frequency of sustaining burns. The least numerous age group comprised children aged 3-5 years (12.6\%), which may result from the fact that children learn caution when in contact with hot surfaces at a relatively young age, even the first year of life [9].

In the presented study, boys were more frequently hospitalized as a result of burns than girls. Analogical conclusions were presented by Gontko et el. [10], Drago [9], Čelko et al. [11], and Yavuz [16].

The family home was decidedly the most frequent scene for the occurrence of burns (91.9\%), which is confirmed by Čelko whose study reported that burns largely take place in the kitchen (70\%) [11]. The kitchen is generally recognized as potentially dangerous for small children. More injuries are suffered during meal preparation than bathing. Parents underestimate the ingenuity of children focused on acquiring access to dangerous devices, and overrate their ability to assess risks [9].

Children largely sustained burns when attended by both parents (66.7\%), and every fifth sufferer was in the mother's care. Studies by Matuszczak et al. confirm that burns are most frequently sustained at unguarded moments and result from children's interest in surrounding objects [1]. Most frequently, children spill hot liquids on themselves, usually from a container above eye level but within their reach; or an inattentive minder spills some hot liquid on them [17]. According to Drago et al., the 2 following patterns of behaviours are prevalent: 'reached up and pulled down a pot from stove or other elevated surface', and 'grabbed, overturned, or spilled pot onto self', accounting for half (52.2\%) of all burn injuries [9].

Analysis of the documentation showed that burns are most often sustained in the afternoons and evenings - 335 patients in total (65.9\%), which is in accordance with research conducted by Auzbiter [18] and Mikołajczyk et al., who proved that the risk of burns is enhanced by adults' and children's increased activity during the day [12].

Burns and scalds may be caused by humid heat (boiling water, water vapour) and other liquid and semi-fluid substances (fat, metal, paraffin, or wax), or dry heat (flame burns or contact burns, e.g. entailing heaters or irons) [2]. The current study shows that children most frequently sustained scalds caused by hot liquids (86.7\%). The same conclusions were provided by Polish research conducted by Matuszczak et al. [1], Gontko et al. [10], Brodzińska [13], Mikołajczyk et al. [12], and a Czech study by Čelko et al. [11]. According to Drago et al., water constituted the most frequent causative factor in $48.5 \%$ cases [9]. However, in Turkey, the causes of thermal injuries were dependent on economic status and weather conditions prevalent in the region. In the poorest region, cold days contributed to burns caused by a heating furnace. Other regions showed the prevalence of contact burns caused by bread ovens (Tandoori), open flame or pots used in producing traditional cheese [16]. The key causative factor remains culture-bound.

Limbs were reported as the body part most frequently burnt in children - 136 individuals (26.8\%), followed by thorax with limbs - 94 patients (18.5\%). Mikołajczyk et al. [12] reported limbs, then thorax followed by thorax with limbs as the most prone to injury, whereas Gontko et al. indicated thorax, limbs, and head [10].

Body parts prone to trigger shock, i.e. head, neck, armpits, perineum, popliteal fossae, and feet, are particularly dangerous burn locations [2].

Moreover, wounds to functionally relevant places, such as face, hands, feet, joints, perineum, and reproductive organs, are difficult to treat and susceptible to early infections followed by deformations and locomotive impairments [9]. Yen et al. reported that children frequently sustain burns due to contact with a hot oven door. Such burns are of specific character in terms of the location on one or both hands, which entails long-term hand function rehabilitation and financial consequences [19].

The severity of burns is determined by the extent and depth of injuries, which are determined through evaluating the proportion of burnt skin to the TBSA [2]. Lund and Browder charts are used with children to evaluate the percentage of wound surface area, including the location and agedependent proportions of children's body parts compared with the TBSA $[2,8]$.

In 260 (51.2\%) of the children hospitalized, the TBSA was evaluated at up to $5 \%$, whereas Gontko et al. reported that most frequent $(48.42 \%)$ hospitalizations were provided to children with the TBSA of 10-19\% [10].

Standards referring to cases of childhood burns differ from the ones adopted for adults. The diversification stems from physiological differences between the bodies of children and adults, as well as distinctive and specific pathophysiology and biology of burns in children, potentially connected with the greater risk of problems and complications [17].

In the period analysed, the great majority of patients required conservative treatment - 454 children (89.4\%). Nevertheless, surgical treatment tends to prevail. Matuszczak et al. reported that most children hospitalized due to burns were also treated conservatively [1].

The length of children's hospital stay depended on the TBSA. Most patients treated conservatively had suffered burns up to $5 \%-251$ individuals (55.3\%), and the average hospitalization time reached 5 days. Similar hospitalization time results with reference to the TBSA was reported by Matuszczak et al. [1].

\section{CONCLUSIONS}

1. Most often, burns affected children at 1-2 years of age, with boys prevailing over girls. 
2. The injuries were largely suffered at the child's family home, in the afternoon or evening, with the child in parents' care.

3. In most cases, burns were caused by hot liquid.

4. The most numerous group of affected children comprised sufferers of burns to limb areas, as well as to thorax with limbs, with the TBSA of up to $5 \%$.

5. The affected patients were largely hospitalized, with the hospitalization period of up to 3 days.

\section{REFERENCES}

1. Matuszczak E, Dębek W, Chomicz A, Dzienis-Koronkiewicz E, Oksiuta M, Hermanowicz A. Analiza etiologii i epidemiologii oraz ocena wyników leczenia oparzeń u dzieci. Pediatr Pol. 2011; 86: 254-259.

2. Kaźmierski M, Mańkowski P, Jankowski A. Rola lekarza rodzinnego w leczeniu oparzeń. Mag Med Lek Rodz. 2002; 11: 33-40.

3. Kłapa Z, Musiał Z, Słowiczek M, Bułat W. Potrzeby edukacyjne rodziców dzieci oparzonych. Stud Med. 2008; 11: 17-21.

4. Kaźmierski M, Mańkowski P, Jankowski A. Zastosowanie opatrunków hydrokoloidowych w leczeniu rany oparzeniowej u dzieci. Mag Med. Dodatek - Oparzenia. 2002; 1: 134-138.

5. Hettiaratchy S, Dziewulski P. Pathophysiology and types of burns. BMJ. 2004; 328: 1427-1429.

6. Stopfkuchen II, Jakubaszko J (ed.) Nagłe zagrożenia zdrowotne u dzieci. MedPharm Polska Wrocław, 2010.

7. Strużyna J. Wczesne leczenie oparzeń. Wyd Lek PZWL Warszawa, 2006.
8. Kurnatowski W. Ciężkie oparzenia - charakterystyka i wskazania terapeutyczne. Zakażenia 2003; 2: 83-88.

9. Drago DA. Kitchen scalds and thermal burns in children five years and younger http://pediatrics.aappublications.org/content/115/1/10. full (access: 13.12.14)

10. Gontko K, Ratajczak K, Naskręt M. Oparzenia u dzieci w województwie wielkopolskim w 2010 roku. Anest Ratow. 2012; 6: 402-408.

11. Brodzińska B. Analiza porównawcza oparzeń leczonych w Oddziale Chirurgii Dziecięcej Oparzeń i Urologii SPS ZOZ „Zdroje” w Szczecinie w latach 1985-1988 i 2006-2010. Leczenie Ran. 2012; 9 (supl. 1): 12-20.

12. Grabowska A, Andrzejewska E, Walczewska A. Czy oparzenia u dzieci powodują zmiany w stężeniu markerów stresu oksydacyjnego w drogach oddechowych. Prz Pediatr. 2004; 34: 232-237.

13. Rawlins JM, Khan AA, Shenton AF, Sharpe DT. Epidemiology and outcome analysis of 208 children with burns attending an emergency department. Pediatr Emerg Care. 2007 May; 23(5): 289-293. http:// www.ncbi.nlm.nih.gov/pubmed/17505269 (access: 13.12.14).

14. Čelko AM, Grivna M, Dáňová J, Barss P. Severe chidhood burns in the Czech Republic: risk factors and prevention. Bull World Health Organ. 2009; 87: 374-381.

15. Yavuz A, Ayse A, Abdullah Y, Belkiz A. Clinical and demographic features of pediatric burns in the ekstern provices of Turkey. Scand J Trauma Resusc Emerg Med. 2011; 19: 6.

16. Puchała J, Spodaryk M, Jarosz J. Oparzenia u dzieci - od urazu do wyleczenia. Wyd UJ Kraków, 1998.

17. Auzbiter S. Przyczyny oparzeń u dzieci. Pielęg Położ. 2002; 7: 6-7.

18. Mikołajczyk A, Porębska A, Łuczyński R. Analiza oparzeń u dzieci do 1-go roku życia. Rocz Oparzeń. 1996-97; 7/8: 163-166.

19. Yen KL, Banku DE, O’Neill AM, Jurta RW. Household oven doors: a burn hazard in children. Arch Pediatr Adolesc Med. 2001; 155(1): 84-86. http://www.ncbi.nlm.nih.gov/pubmed/11177068 (access: 13.12.14). 